\title{
Studies of the Woody Vegetation of the Welor Forest Reserve (Senegal) for Sustainable Use
}

\author{
B. Sambou*, A. T. Bâ, C. Mbow and A. Goudiaby \\ Institute of Environmental Sciences, Faculty of Sciences and Techniques, \\ University Cheikh Anta Diop, Dakar-Fann, BP 5005, Senegal \\ *Corresponding author; E-mail: bienvenu_sambou@yahoo.fr
}

\begin{abstract}
The Welor area has been classified as a forest reserve since 1935 while waiting for the outcome of studies for its appropriate exploitation based on its biological potential. Due to lack of information on this potential, the plant resources of this forest reserve have been used improperly and excessively. The present study aims at gathering, with an appropriate approach and efficient tools, information necessary for designing a management plan to ensure a sustainable use of the woody resources of Welor Forest Reserve. The results obtained have provided information on the present condition of the woody flora and the vegetation, the potential and the dynamics of the most exploited woody species, and the root causes of the present state of the vegetation of the Welor Forest Reserve. Forty-six woody species, which belong to 39 genera and 25 families, were identified in this Forest Reserve. The most numerous families were Combretaceae, Capparidaceae, Mimosaceae and Caesalpiniaceae. The shrubs represented about $95 \%$ of the woody individuals. The average density of the woody individuals was $75-181$ individuals per hectare. Acacia seyal and Balanites aegyptiaca were the dominant woody species with the best population structure. None of the woody species exploited for timber reveals a good structure and a good regeneration. Considering the socio-economic context of the area, it appears that the Welor Forest Reserve could be used as a source for firewood.
\end{abstract}

\section{Introduction}

The degradation of the vegetation has considerably affected the environment in the Sahel during the last few decades. In Senegal, the regression of the plant formations noticed in 1980 was confirmed during the 1980-1990 decade (Anon.,1993). A number of historical reports, cartographic works, selected surveys and recent observa-tions have led to the common agreement that plant resources have gradually been degrading (Anon., 2005). Even the so-called forest reserves have been affected by degradation despite their being protected. At present, some of them are characterized by a reduction of their initial area, a drastic drop of the biodiversity, a reduction of the density of the woody species, and a degradation of the structure of some species population (Sambou, 2004).

Considering that threat, the administrative and political authorities have undertaken some institutional reforms, some modifica-tions of the legal rules and regulations, and a new approach to the management of the plant resources. These reforms led to the formulation of the 1993 and 1998 forest codes, as well as the 1996 laws relating to the local communities code and the transfer of competences to the local communities in the field of natural resources management (Anon., 1999). The local reforms and participatory approaches aim at an involve-ment and empowerment of the stakeholders for the promotion of a participatory management and sustainable use of the natural resources. However, the partici-patory management of the plant resources is considerably hampered by the insuf-ficiency, if not a total absence, of appropriate and up-to-date data on the flora and the vegetation of the forest reserves.

The objective of this study is to collect data by means of an easily accessible and cheap method compared to the usual ones, to find out the most suitable exploitation system for a sustainable use of the woody resources.

Study area

\section{Materials and methods}

The Welor Forest Reserve is located in the district of Djilor, department of Foundiougne (west centre of Senegal) (Fig. 1). It is situated in the Sudanian domain between the 700 and $800 \mathrm{~mm}$ isohyets (period 1971-1998). It covers an area of 5469 hectares characterized by large plateaus and many valleys or ponds

West African Journal of Applied Ecology - Volume 13 
quickly filled during the rainy season (Stancioff et al., 1986). The soils on the plateaus are mostly ferruginous. In the valleys and the ponds, the soils are rather clayey (hydromorphic to pseudogley soils or halomorphic soils). In 1935, when the site was held in forest reserve, the vegetation was characterized by shrub savanna and savanna woodland (Trochain, 1940; Adam, 1966; Lawesson, 1995; Sambou, 2004).

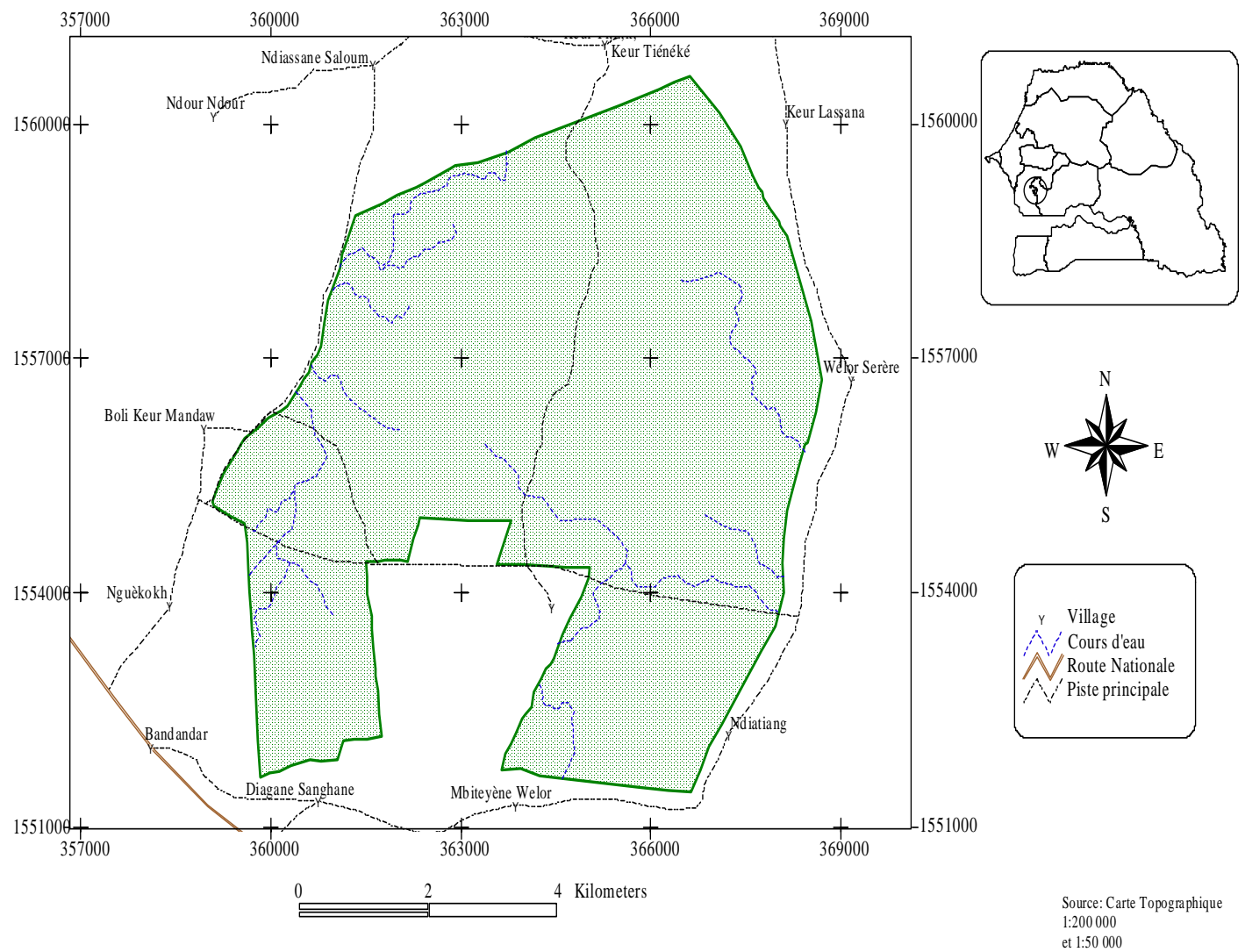

Fig. 1. Map of the Welor Forest Reserve 


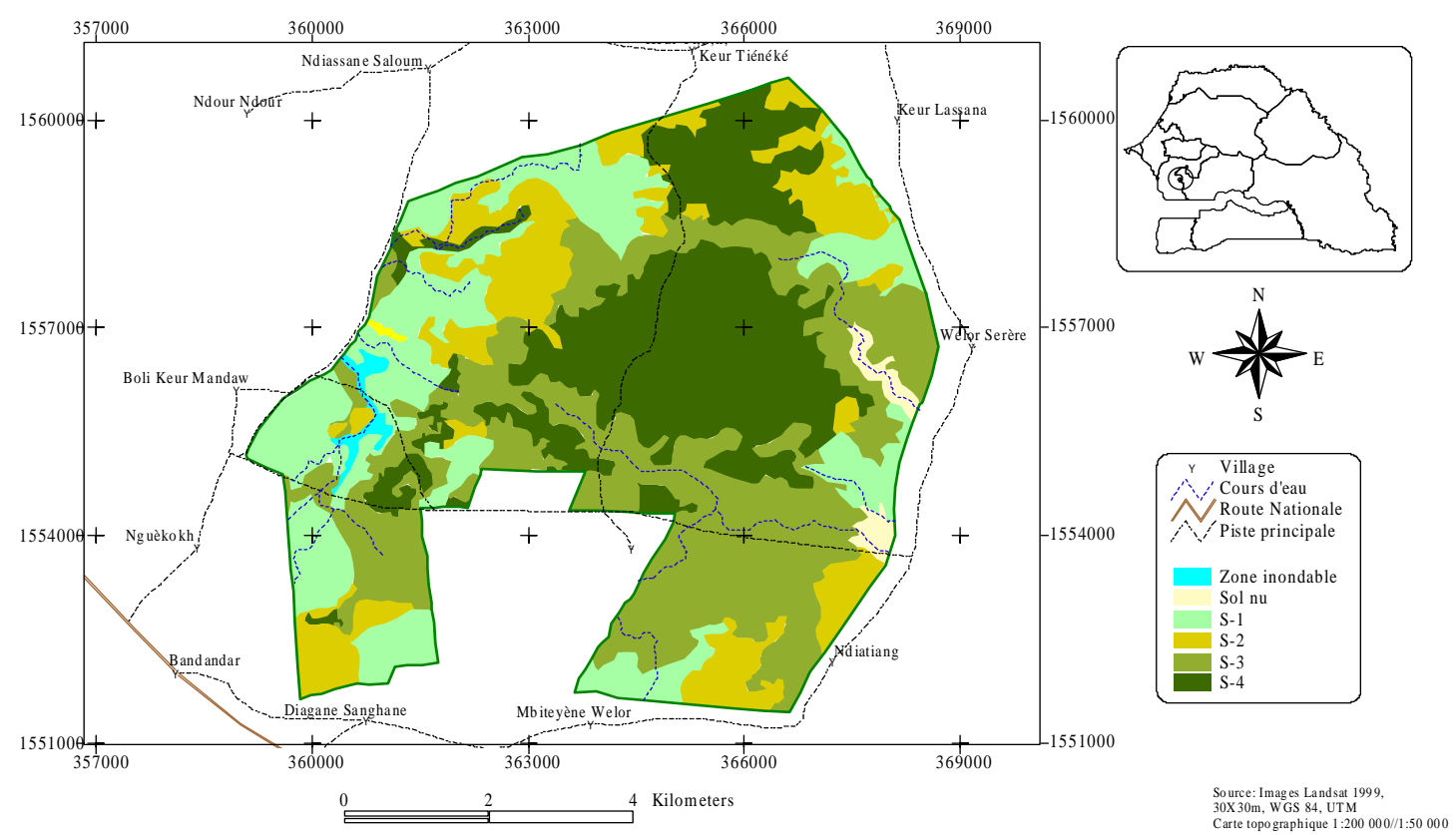

Source: Images Landsat 1999

30 x 30 m WGS 84, UTM

Carte topographyique 1:200 000/1:50 000

Fig. 2. Stratification of the Welor Forest Reserve

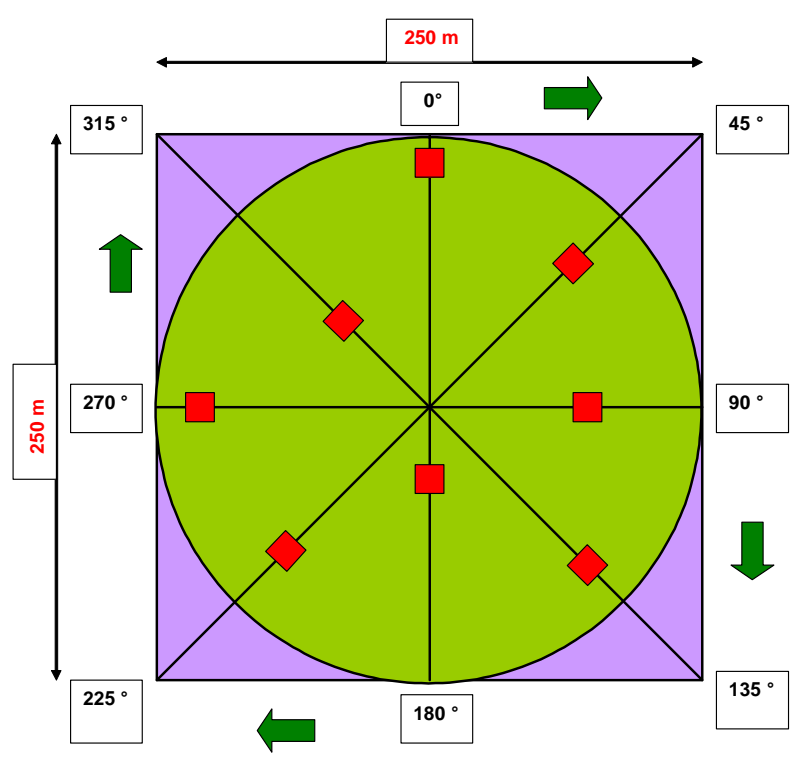

Fig. 3. Layout of the 8 sub-plots within the plot

West African Journal of Applied Ecology - Volume 13 
The species indicated as dominant species in 1935 in the legal instrument relating to the Forest Reserve are Sterculia setigera, Lannea acida, Sclerocarya birrea, Adansonia digitata, Acacia seyal, Com-bretum glutinosum, Acacia macrostachya and Securidaca longepedunculata. The 1988 national census revealed that the average density of the population of the region was of $47.5 \mathrm{per} \mathrm{km}^{2}$. The main ethnic groups are the Wolofs (39.1\%) and the Sereres (37.7\%). The other ones are the Fulanis (9\%), the Mandinkas (7.1\%) and the Bambaras (2.2\%). The main socio-economic activities of the people in the neighbouring villages are agriculture, cattle rearing, and the exploitation of the forest resources (Stancioff et al., 1986).

\section{Data collecting and processing}

The data used to assess the flora and the vegetation derive from a review of the literature, an inventory of the woody flora and the vegetation, and interview with resource person. The woody flora and the vegetation inventory method used a 2-level sampling based on a preliminary stratification of the vegetation (Fig. 2). The stratification was achieved from a Landsat-ETM satellite image of the area (image of December 1999), following the procedures used by Guellec (1980) and Sambou (2004). The sampling of the woody flora and the vegetation was carried out on the main identified strata (S1, S2, S3 and S4) which cover $97.8 \%$ of the total area of the Forest Reserve. Each of these strata was subdivided into $250 \mathrm{~m} \times 250 \mathrm{~m}$ plot to set up a "population of plots". To get homogeneous populations, all plots straddling two strata were discarded. A sample plot was set up by random selection. Eight sub-plots of 20 $\mathrm{m} \times 20 \mathrm{~m}$ were chosen at random from each selected plot (Fig. 3).

The following rates of sampling was adopted: $0.49 \%$ for stratum S1, $0.46 \%$ for stratum S2, $0.48 \%$ for stratum S3 and $0.47 \%$ for stratum S4. These rates of sampling were adjusted to the area, the density and the diversity of each stratum. The location of the selected plots and sub-plots was carried out by means of a GPS, two compasses and two 50-metre ribbons. The data gathered from the sub-plots were processed to specify the woody flora and the vegetation, and to assess the woody species potential and the evolutionary trends of the exploited woody species population.

\section{Characteristics of the woody flora}

\section{Results}

Forty-six woody species which belong to 39 genera and 25 families were identified in this Forest Reserve. Thirty-two species were found in the stratum S1, 27 in S2, 39 in S3, and 32 in S4. Nine species were found in one stratum (two species in S1, four in S3 and three in S4).

The most numerous families were Combretaceae, Capparidaceae, Mimo-saceae and Caesalpiniaceae.

\section{Characteristics of the vegetation}

The characteristics of the vegetation were defined by the proportion of ground cover area by the crowns of the woody individuals, the density of the woody individuals, the proportion of the shrubs (less than $7 \mathrm{~m} \mathrm{high}$ ) and those of the trees (more than $7 \mathrm{~m} \mathrm{high}$ ), and the structure of the woody species populations. The average proportion of ground cover area by the crowns of the woody individuals was estimated at $8.5 \%$ in stratum S1, 9.5\% in stratum S2, $12.3 \%$ in stratum S3 and 15\% in stratum S4.

The average density of the woody individuals was 99 individuals per hectare in stratum S1, 75 individuals per hectare in stratum S2, 133 individuals per hectare in stratum S3 and 181 individuals per hectare in stratum S4. The shrubs represented about $95 \%$ of the woody individuals while the trees represented approximately 5\%. Acacia seyal and Balanites aegyptiaca (shrubs of 4-5 m high) were the dominant woody species in the four strata. The distribution of the adult individuals in DBH size classes of $5 \mathrm{~cm}$ (Tables 1, 2, 3 and 4) gives information on the present condition and evolutionary trends of the woody species populations. It shows that Acacia seyal (main species exploited as firewood), and Balanites aegyptiaca (species exploited for its fruits) have a good structure. None of the woody species exploited for timber reveals a good structure and a good regeneration (DBH size class less than $5 \mathrm{~cm}$ ).

West African Journal of Applied Ecology - Volume 13 
TABLE 1

Woody species population structure in stratum SI

Species main uses

Timber

Lannea acida

Sclerocarya birrea

Borassus aethiopum

Firewood

Acacia seyal

Combretum glutinosum

Anogeissus leiocarpus

Acacia macrostachya

Non-ligneous products

Ziziphus mauritiana

Balanites aegyptiaca

Guiera senegalensis

Grewia bicolor

Securidaca longepedunculata

Tamarindus indica

Neocarya macrophylla

Barely exploited

Dicrostachys cinerea

Mitragyna inermis

Ximenia americana

Acacia senegal

Acacia sieberiana

Commiphora africana

Crateva andansoni

Stereospermum kunthianum

Cadaba farinosa

Securinega virosa

Calotropis procera

Maerua angolensis

Strophantus sarmentosus

Boscia sp.

Azadirachta indica

Piliostigma reticulatum

Combretum aculeatum
Feretia apodanthera

NR1 NR2 5-10 $<10-15<15-20<20-25<25-30<30-35$

1551282

110234

181

42

4

1

2

$\begin{array}{ll}5 & 1 \\ & 1 \\ 1 & 1\end{array}$

\begin{tabular}{|c|c|c|c|c|c|}
\hline 2 & 9 & 3 & 2 & & 1 \\
\hline 33 & 208 & 21 & 5 & 3 & \\
\hline 1 & 6 & 1 & & & \\
\hline & 3 & 2 & & & \\
\hline 1 & & & & & \\
\hline 1 & 3 & & & & \\
\hline 5 & 679 & 2 & 5 & 5 & 3 \\
\hline
\end{tabular}

NR1 : Individuals of diameter less than $5 \mathrm{~cm}$ and height less than $1.30 \mathrm{~m}$

NR2 : Individuals of diameter less than $5 \mathrm{~cm}$ and height more than $1.30 \mathrm{~m}$

TABLE 2

Woody species population structure in stratum $S 2$

Species main uses

NR1

$N R 2$

$5-10<10-15$

$<15-20$

$<20-25$

$<25-30<45-50<50$

Timber

Borassus aethiopum

Lannea acida

1

West African Journal of Applied Ecology - Volume 13 
Firewood

Acacia seyal

Anogeissus leiocarpus

$108 \quad 902$

62

$\begin{array}{rr}13 & 2 \\ 1 & 3\end{array}$

2

1

Non-ligneous products

Balanites aegyptiaca

Ziziphus mauritiana

Tamarindus indica

$\begin{array}{rrrr}41 & 70 & 17 & 1 \\ 6 & 1 & 1\end{array}$

Adansonia digitata

Barely exploited

Mitragyna inermis

Dicrostachys cinerea

Feretia apodanthera

Grewia bicolor

Ximenia americana

Commiphora africana

Combretum aculeatum

Azadirachta indica

Gardenia sp.

$11 \quad 119$

$112 \quad 175$

1

Hexalobus monopetalus

Piliostigma reticulatum

Boscia sp.

Cadaba farinosa

Guiera senegalensis

Maerua angolensis

Sclerocarya birrea

$\begin{array}{rrrr} & 2 & 5 & 1 \\ 16 & 436 & 3 & \\ 4 & 63 & 1 & \\ 2 & 31 & 1 & \\ & 10 & 1 & \\ & 2 & 1 & 1 \\ & 1 & & \end{array}$

2

2

11

15

8

$2 \quad 6$

18

NR1 : Individuals of diameter less than $5 \mathrm{~cm}$ and height less than $1.30 \mathrm{~m}$

$\mathrm{NR} 2$ : Individuals of diameter less than $5 \mathrm{~cm}$ and height more than $1.30 \mathrm{~m}$

TABLE 4

Woody species population structure in stratum S4

Species main uses

NR1 NR2 $5-10<10-15<15-20<20-25<25-30<30-35<35-40<40-45<50$

Timber

Lannea acida

1

27

1

2

Firewood

Acacia seyal

$\begin{array}{lll}487 & 1189 & 497\end{array}$

Combretum glutinosum $238 \quad 294 \quad 45$

Anogeissus leiocarpus

Combretum nigricans

Acacia macrostachya

$\begin{array}{lll}15 & 78 & 3\end{array}$

$\begin{array}{lll}83 & 5 & 1\end{array}$

$\begin{array}{lllll}78 & 3 & 1 & 1 & 1\end{array}$

Non-ligneous products

Balanites aegyptiaca

Ziziphus mauritiana

Tamarindus indica

Sterculia setigera

Adansonia digitata

$\begin{array}{rrrrrr}34 & 149 & 40 & 18 & 8 & 1 \\ 1 & 2 & 3 & 1 & & \\ & 2 & 3 & 2 & 1 & \end{array}$

Barely exploited

$\begin{array}{lllll}\text { Feretia apodanthera } & 47 & 404 & 69 & 1\end{array}$

Mitragyna inermis

$\begin{array}{llll}4 & 187 & 43 & 16\end{array}$

West African Journal of Applied Ecology - Volume 13 


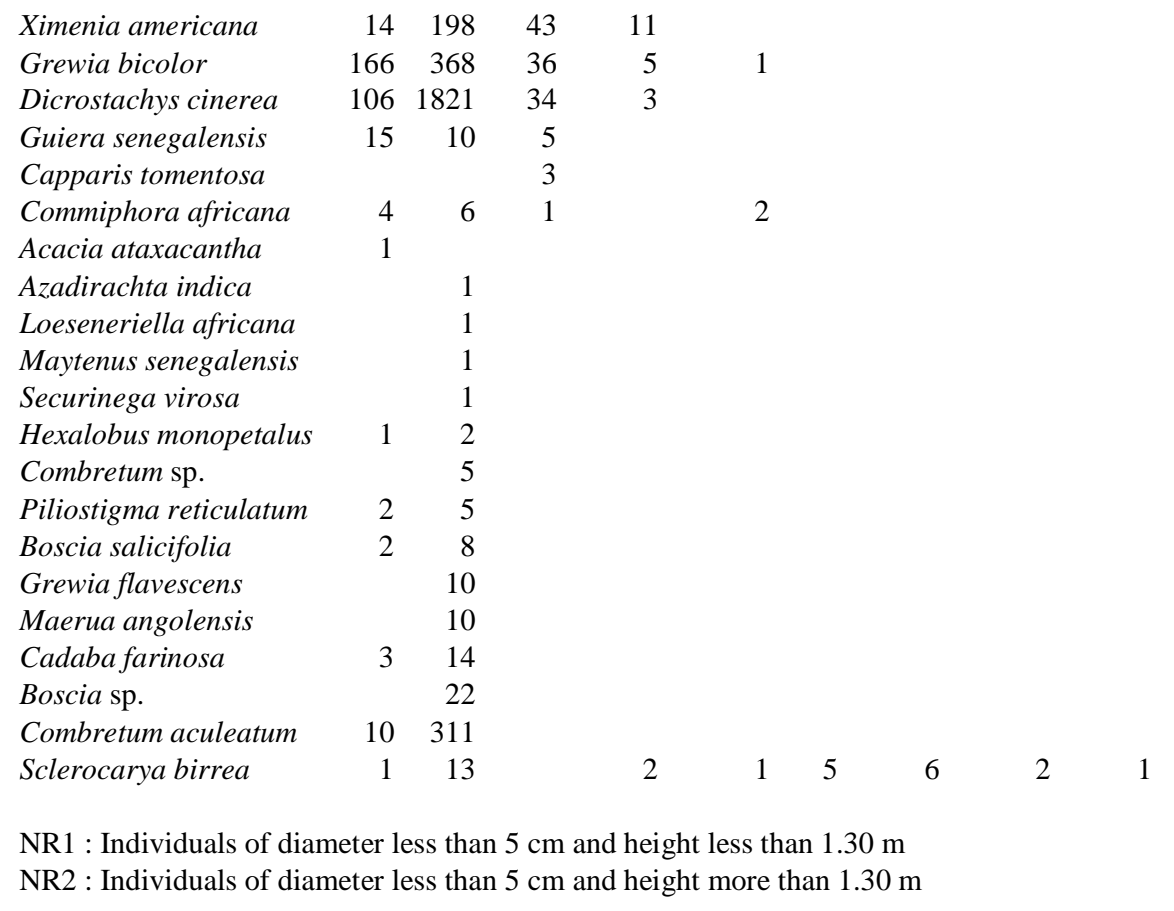

\section{Woody species potential}

Calculated on the basis of their average densities in the different strata and the area of the strata, the abundance of the woody species has been estimated at 110828 individuals in stratum S1, 65026 individuals in stratum S2, 244994 individuals in stratum S3 and 275681 individuals in stratum S4; these amount to $16 \%$ of the individuals in S1, 9\% in S2, 35\% in S3 and 39\% in S4. Fig. 4 illustrates the proportions of the different categories of species based on their economic importance.

The species exploited as sources of energy are the most numerous (between 66 and 76\%), followed by those exploited as non-ligneous plant products (between 8 and 25\%) and those used as timber (between 1 and $2 \%$ ). The species which are barely exploited represent $8-20 \%$ of the whole population.

\section{Discussion}

The woody flora of the Welor Forest Reserve (46 species) is relatively important compared to those of the Kouyong Island Forest Reserve and the Djilor Forest Reserve, located in the same eco-geographical zone. Thirty-one and 38 woody species were identified in the Kouyong Island Forest Reserve and the Djilor Forest Reserve, respectively (Sambou et al., 1994). Acacia seyal was the dominant species in the two forest reserves. The proportion of ground cover area by the crowns of the woody individuals (8.5-15.9\%) was low compared to that in the Djilor Forest Reserve (39-70\%). It was the same as far as the woody individuals' density was concerned (75-180 individuals/ha against 188-275 individuals/ha in the Djilor Forest Reserve). The proportion of shrubs (about $95 \%$ of the woody species) was very high compared to that of trees (5\%). It can be concluded that the Welor Forest Reserve is characterized by a shrub savanna dominated by Acacia seyal, based on the classification of Adam (1966).

Out of the 46 woody species of the Welor Forest Reserve, four were exploited for timber (Lannea acida, Cordyla pinnata,Bombax costatum and Borassus aeth-iopum), five as firewood (Acacia seyal, Acacia macrostachya, Combretum gluti-nosum, Combretum nigricans and Anog-eissus leiocarpus) and seven for non ligneous products (Balanites aegyptiaca, Neocarya macrophylla, Ziziphus mauri-tiana,

West African Journal of Applied Ecology - Volume 13 
Acacia senegal, Tamarindus indica, Adansonia digitata and Sterculia setigera). Firewood exploitation was most prominent (Fig. 4 and Fig. 5).



Fig. 4. Potential of the most exploited woody species in the Welor Forest Reserve (strata S1 and S2)

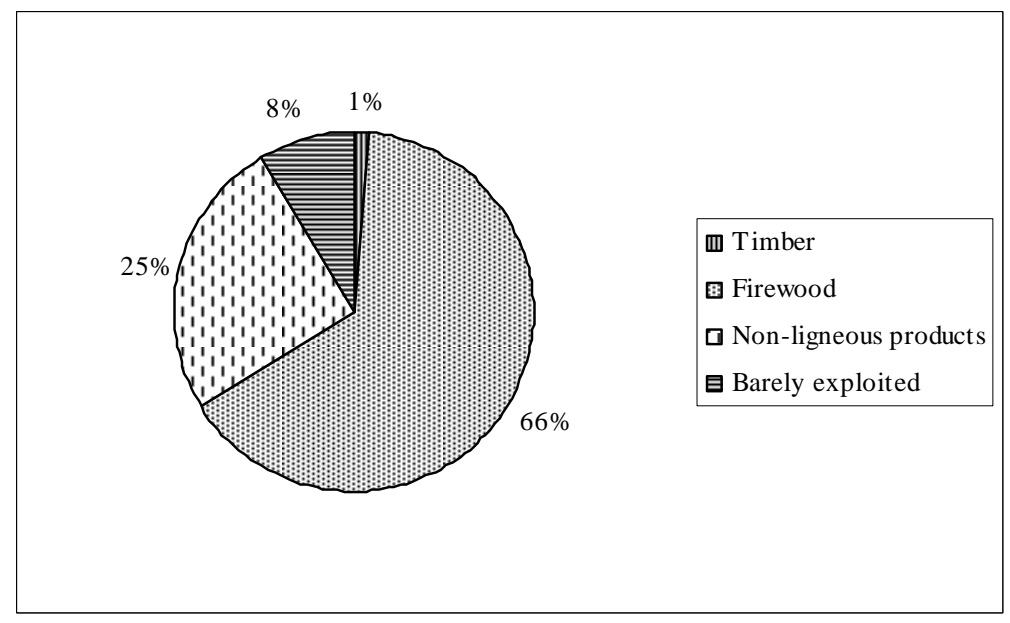

West African Journal of Applied Ecology - Volume 13 


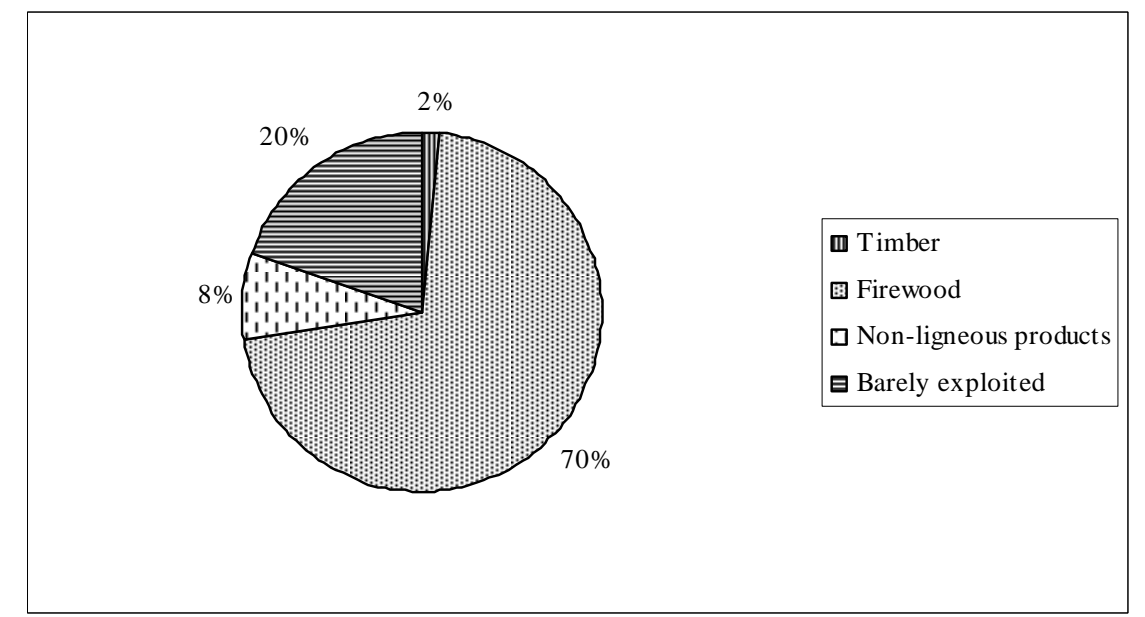

Fig. 5. Potential of the most exploited woody species in the Welor Forest Reserve (strata S3 and S4)

The structure of the exploited species populations gives information on their viability, in other words, on their ability to regenerate (Condit et al., 1998; Swaine et al., 1990; Sambou, 2004). The Acacia seyal populations (used to produce charcoal) and the Balanites aegyptiaca (exploited for their fruits) which have a positive evolutionary trend were the only viable ones in the Forest Reserve. Acacia seyal populations were characterized by the large area they cover, a high adult individual density, a good distribution of individuals in the DBH size classes, and an abundant natural regenera-tion. Such characteristics revealed that the ecological conditions of the site were favourable for development of the species (Lykke \& Sambou, 1998). None of the timber species could regenerate.

Among the eight woody species labelled as the dominant ones when the area was classified as a Forest Reserve in 1935, Acacia seyal remained the only abundant species. The other species were hardly represented and their populations were characterized by a degraded structure. The Welor Forest Reserve was one of the few host sites of the area for the livestock during the 4-month rainy season. The natural regeneration of the preferred species was then under heavy pressure due to the concentration of a large number of cattle in that grazing area (Sambou et al., 1994).

\section{Conclusion}

The study provides useful information on the present condition of the woody flora and the vegetation of the Welor Forest Reserve and their evolutionary trends. The main strata of the plant formation were identified and their characteristics defined. The woody flora was relatively conserved compared to other sites located in the same eco-geographical zone. The most important vegetation type was a shrub savanna dominated by Acacia seyal and Balanites aegyptiaca. The potential of the species exploited as sources of energy was the most important. The study also showed signs of degradation in the Forest Reserve. The structure of the woody species populations showed that only two species, Acacia seyal and Balanites aegyptiaca, had the potential to regenerate. None of the woody species exploited for timber showed a good structure and natural regeneration. From the gathered information and considering the socioeconomic context of the area, it appears that the Welor Forest Reserve could be mostly used as a source for sustainable use of firewood.

\section{Acknowledgement}

The authors would like to express their profound gratitude to the Danish Cooperation (DANIDA) for the financial support to the ENRECA project No 104. Dan. 8L/203, which has enabled them to carry out the study, and to the Institute of Environmental Sciences, Cheikh Anta Diop University, for assistance granted to the project.

West African Journal of Applied Ecology - Volume 13 


\section{References}

Adam J. G. (1966). Composition floristique des principaux types physionomiques de végétation du Sénégal. J. West Afr. Sci. Ass. 11(1-2): 81-97.

Anon. (1993). Plan d'Action Forestier, vol. II. Rapport national. 147 pp.

Anon. (1999). Code Forestier - Loi $n^{\circ}$ 98/03 du 08 janvier 1998 - Décret $n^{\circ}$ 98/164 du 20 janvier 1998. Ministère de l'Environnement et de la Protection de la Nature, Direction des Eaux Forêts Chasse et de la Conservation des Sols, République du Sénégal. 42 pp.

Anon. (2005). Politique Forestière du Sénégal - Résumé exécutif. Ministère de l'Environnement et de la Protection de la Nature, Direction des Eaux Forêts Chasse et de la Conservation des Sols, République du Sénégal. 37 pp.

Condit R., Sukumar R., Hubbell, S. P. and Foster R. B. (1998). Predicting population trends from size distributions: a direct test in a tropical tree community. Am. Nat. 152: 495-509.

Guellec J. (1980). Possibilités d'utilisation d'images LANDSAT améliorées à l'échelle de 1/200000 pour la connaissance des forêts. Interprétation et cartographie des types de végétation ligneuse et d'occupation du sol en zone soudano-guinéenne. Bois Forêts Trop. 193: 41-47.

Lawesson J. E. (1995). Studies of woody flora and vegetation in Senegal. Op. bot. 125. 172 pp.

Lykke A. M. and Sambou B. (1998). Structure, floristic composition, and vegetation forming factors of three vegetation types in Senegal. Nord. J. Bot. 18(2): 129-140.

Sambou B. (2004). Evaluation de l'Etat, de la dynamique et des tendances évolutives de la flore et de la végétation ligneuses dans les domaines soudanien et sub-guinéen du Sénégal. (Thèse de Doctorat d'Etat.) Institut des Sciences de l'Environnement, Faculté des Sciences et Techniques, Université Cheikh Anta Diop. 210 pp.

Sambou B., Goudiaby, A., Madsen J. E. and Bâ A. T. (1994). Etude comparative des modifications de la flore et de la végétation ligneuses dans les Forêts Classées de Koutal et de l'île Kouyong (Centre-Ouest du Sénégal). J. Agric. trop Bot. appl. n. s. XXXVI (1): 87-100.

Stancioff A. Staljanssens M. and Tappan G. (1986). Cartographie et Télédétection des Ressources de la République du Sénégal : étude de la géologie, de l'hydrologie, des sols, de la végétation et des potentiels d'utilisation des Sols. Remote Sensing Institute, South Dakota State University, SDSU-RSI-86-01. 653 pp.

Swaine M. D., Lieberman D. and Hall J. B. (1990). Structure and dynamics of a tropical dry forest in Ghana. Vegetatio. 88: 3151.

Trochain J. (1940). Contribution à l'étude de la végétation du Sénégal. Mémoire de l'Institut Français d'Afrique Noire. 433 pp. 